\title{
Nitrogen Fertilizer Effects on Quality of Fodder beet (Beta vulgaris var. Crassa)*
}

\author{
Muna E.Khogali ${ }^{1}$, Yassin M.I.Dagash ${ }^{2}$ and Mahgoub G.EL-Hag ${ }^{3}$ \\ ${ }^{1}$ Department of Animal Production, Faculty of Sciences and Technology of Animal \\ Production, Sudan University of Science and Technology, Khartoum North (Kuku), Sudan \\ ${ }^{2}$ Department of Field Crops Sciences, Faculty of Agricultural Studies, Sudan University of \\ Science and Technology, Shambat, Sudan \\ ${ }^{3}$ Department of Animal Production, Faculty of Agriculture, Al zaiem Alazhary University, \\ Khartoum North, Sudan
}

\begin{abstract}
:
A field experiment was carried out for two consecutive seasons (2007/08 - 2008/09), at the Demonstration Farm of the College of Agricultural Studies (Shambat), Sudan University of Science and Technology, to study the effect of nitrogen fertilization on quality of three fodder beet cultivars. Nitrogen treatments at a rate of $0,40,80$ and $120 \mathrm{~kg} \mathrm{~N} / \mathrm{ha}$ were assigned to the main plots . Three fodder beet cultivars (Voroshenger, Anisa and Polyproductiva) were allotted to the sub-plots. Nitrogen fertilization reduced dry matter content highly significantly $(p<0.01)$. However, it increased crude protein and ether extract highly significantly $(p<0.01)$ and crude fiber significantly $(p<0.05)$ in the first season and crude protein and nitrogen free extract significantly $(p<0.05)$ in the second season. Leaves exceeded tubers in crude protein, crude fiber and ash highly significantly $(p<0.01)$ while tubers were superior over leaves in dry matter and nitrogen free extract. Tubers without nitrogen fertilization and under 40 and $120 \mathrm{~kg} \mathrm{~N} / \mathrm{ha}$ highly significantly $(p<0.01)$ attained the greatest dry matter and nitrogen free extract. Leaves with 40 and $120 \mathrm{~kg} \mathrm{~N} / \mathrm{ha}$ recorded the highest crude protein and crude fiber. Leaves under 40 and $80 \mathrm{~kg}$ $\mathrm{N} / \mathrm{ha}$ attained the highest ether extract while those with 80 and $120 \mathrm{~kg} \mathrm{~N} / \mathrm{ha}$ recorded the greatest ash contents. Nitrogen, phosphorus, sodium, magnesium, zink and iron were significantly $(p<0.05)$ increased by nitrogen fertilization while calcium was reduced. Sulfur and chloride showed inconsistent response to nitrogen fertilization. Leaves contents of nitrogen, phosphorus, calcium, magnesium and zink were higher than tubers and the reverse was true for potassium and sodium.
\end{abstract}

Keywords: Nitrogen fertilization, Quality, Fodder beet, Cultivars.

\section{INTRDUCTION}

Fodder beet (Beta vulgaris spp. vulgaris), a member of the chenopodiaceae family (www.ars-grin.gov, 1987), is also known as mangel (Martin, 1976). The fodder beet is a native of Mediterranean area and was grown as a root crop in Germany and Italy as early as the Sixteenth Century. The crop was introduced into the United States in colonial days (Kipps, 1970). It is World-wide in temperate zones up to $55^{\circ} \mathrm{N}$ (WWW.biolaie.uni-hambura.de, 2006).

In the evaluation of forage crops, yield must be coupled with quality to make the product more useful and more appealing to the animal (Cooper, 1972). The chemical composition of fodder beet varies between cultivars, growing conditions, tops and root of the plant (Magat and Goh, 1990). The fodder beet tubers were nutritive and could be a good source of carbohydrates. The tubers were very rich in starch (NFE $=81 \%$ of dry matter) (Nadaf et al.,1998b). Crude protein (CP) content of the leaves ranged between 11.4 and $15.8 \%$, while the tubers contained between 4.5 and $9.8 \%$ of crude protein (Nadaf et al.,1998a). Fodder beet tops and roots are succulent, palatable and easily digestible and liked by most livestock (Chatterjee and Das, 1989).Fodder beet has a high dry matter yield, and recognized for its high nutritional value as it is a good source of energy for animals (Ibrahim, 2005). Its content of carbohydrates is about 71.69\% dry matters (Abdallah and Yassen, 2008). The fodder beet has a high nutritive value equivalent to 9.69 tons of feed barely (Paska, 1994). Also, the calculated energy content of fodder beet (tubers and leaves) was about $61 \%$ TDN compared to $58 \%$ for Rhodes grass (Nadaf et al. 1998b). 
Nitrogen is often the most limiting factor in crop production. Hence, application of fertilizer nitrogen results in higher biomass yield and protein yield and concentration in plant tissue is commonly increased (Blumenthal et al., 2008 and Patel et al., 2007). Also, nitrogen fertilization enhances absorption of the mineral from the soil (Nollar and Rhykerd, 1974).

The objectives of this research are to determine the nutritive value and chemical composition of fodder beet as affected by nitrogen fertilization.

\section{MATERIALS AND METHODS}

Location: A field experiment was conducted in the Demonstration Farm of the College of Agricultural Studies, Sudan University of Science and Technology at Shambat Khartoum North, during the two successive winter seasons of November 20072008 and 2008-2009, to study the quality of three fodder beet cultivars (Beta vulgaris L.), viz., Voroshenger (Hungarian) , Anisa (Italian) and Polyproductiva (Polish) under different nitrogen fertilization levels. The latitude of the location is $15^{\circ}$ $40^{\prime} \mathrm{N}$ and Longitude is $32^{\circ} 32^{\prime} \mathrm{E}$.

Land preparation: The land was ploughed by a disc plough $(40 \mathrm{~cm})$, harrowed twice, leveled and ridged up $70 \mathrm{~cm}$ apart.

Experimental design: A two factors experiment was conducted in a randomized complete block design (RCBD) arranged in split- plots and four replications. Four nitrogen fertilization levels were applied to the main plots and three cultivars were sown on the subplots $\left(9 \mathrm{~m}^{2}\right)$ in four rows of $3.21 \mathrm{~m}$ length.

Planting: Fodder beet seeds of the three studied cultivars, imported from Egypt, were sown at a rate of $4.6 \mathrm{~kg} / \mathrm{ha}$ on November 30 and 13 in the first and second season, respectively. Seeds were planted on top of the shoulder of the ridge (3 seeds per hole).

Treatments: Nitrogen fertilization in the form of urea $(46 \% \mathrm{~N})$, was broadcasted once before the third irrigation (11 days from planting) at a rate of 0 (N0) as control, 40 (N1), 80 (N2), and 120 (N3) kg N/ha. Triple superphosphate $\left(46 \% \mathrm{P}_{2} \mathrm{O}_{5}\right)$ was added preplanting at a rate of $100 \mathrm{~kg} / \mathrm{fed}$. as agronomic practice.

The frequency of irrigation was at 7-10 days intervals depending on the temperature, relative humidity and soil moisture conditions. Hand thinning to one plant per hole and resowing by the removed seedlings were done simultaneously after 5-6 weeks from planting during both seasons. Manual weeding by a hand implement"Nagama" was done, after 5 weeks from planting in the two seasons.

Determination of nutritive value: Bulk samples of the fodder beet crop under four nitrogen levels were chopped into thin slices thoroughly mixed and dried at $105^{\circ} \mathrm{C}$ to constant weights for leaves or roots to obtain their dry matter percentages. Then the dried samples were ground by an electrical grinder to pass through a $1 \mathrm{~mm}$ diameter thieve and kept for analysis. Proximate analysis for nutritive value was carried following the conventional methods recommended by A.O.A.C (1984):

1- Crude protein percentage (CP \%) was determined by micro-Kjeldahl method ( $N \% \mathrm{X}$ 6.25).

2- Crude fiber percentage (CF \%).

3- Ash percentage (ASH\%).

4- Ether extract percentage (EE \%).

5- Nitrogen free extract percentage (NFE\%) obtained by difference as follow:

$\mathrm{NFE} \%=100-(\mathrm{Ash} \%+\mathrm{CP} \%+\mathrm{CF} \%+\mathrm{EE} \%$ on $\mathrm{dm}$ basis).

Minerals determination: Nitrogen percentage ( $\mathrm{N} \%)$ was calculated earlier in determining crude protein percentage. Each sample of the dried fodder beet crop was ashed in a muffle furnace at $550^{\circ}-600^{\circ} \mathrm{C}$ for three hours to obtain the ash and making mineral abstract according to Chapman and Pratt (1961).

Sodium and potassium percentages ( $\mathrm{Na} \%$ and $\mathrm{K} \%$ ) were tested by Corning 400 flame photometer. Percentages of calcium, Magnesium, Sulfur, Chloride, Phosphorus, iron (ppm) and Zinc (ppm) were determined by atomic absorption spectrophotometer (AA.6800, SHIMADZU).

Statistical analysis: Data for each season were analyzed by standard analysis of variance (ANOVA) of the split- plot design. The treatment means were compared using Duncan Multiple Range Test (D.M.R.T) and Least Significant Difference (LSD) procedures at 5\% level (Gomez and Gomez, 1984) using MSTAT Computer Program v.4 (1986).

\section{RESULTS AND DISCUSSION}

Nutritive value: Table(1) shows the effects of nitrogen ,beet parts and their interaction on $\mathrm{DM} \%, \mathrm{CP} \%, \mathrm{CF} \%, \mathrm{EE} \%, \mathrm{ASH} \%$ and $\mathrm{NFE} \%$ of fodder beet.

Dry matter\%: In both seasons nitrogen fertilization highly significantly decreased dry matter percentage. Increasing fertilization with nitrogen tends to increase cell volume and hence increased moisture content; 
thus the dry matter content of forage tends to decline (Vansoest, 1982).

The highly significant difference in dry matter between leaves and tubers was supported by the finding of Nadaf et al. (1998a) who found higher dry matter in tubers compared to leaves.

Nitrogen $X$ beet parts had a highly significant effect on dry matter percentage. Tubers without nitrogen $\left(N_{0} T\right)$ in the first season and that under $40 \mathrm{~kg} \mathrm{~N} / \mathrm{ha}$ $\left(\mathrm{N}_{1} \mathrm{~T}\right)$ in the second one attained the greatest dry matter content. This finding is in line with those obtained by Mustafa (2007) who reported that nitrogen tended to increase root moisture content.

Crude protein\%: Raising nitrogen fertilization level up to $80 \mathrm{Kg} \mathrm{N} / \mathrm{ha}\left(\mathrm{N}_{2}\right)$ resulted in a highly significant increase in CP\% in the first season and a significant one in the second season (Table 1), this agrees with Patel et al. (2007).

Leaves had higher crude protein than tubers in both seasons. Nadaf et al. (1998a) reported that crude protein of the leaves ranged between 11.4 and $15.8 \%$, while the tubers contained between 4.5 and $9.8 \%$.

Nitrogen application $X$ beet leaves and tubers interaction effect on crude protein was highly significant in both seasons. Leaves under different nitrogen levels attained the highest crude protein percentages indicating that leaves were the main sink for nitrogen (Marschner, 1988).

Crude fibre\%: CF\% was increased by application of nitrogen fertilization and a significant difference was obtained under $120 \mathrm{Kg} \mathrm{N} / \mathrm{ha}$ (N3) in the first season only. This result is in line with those reported by Mustafa (2007) for some sugar beet cultivars in the Sudan. Leaves had significantly higher crude fibre content than tubers. Nadaf et al. (1998b) investigated the nutritive value of bulk samples of fodder beet leaves and roots. It was found that beet tubers were low in crude fibre $(C F=5.8 \%$ of $D M)$ compared to leaves $(C F=10 \%$ of $D M)$.

The interaction effect between nitrogen fertilization and fodder beet leaves and tubers was significant in the second season when the combination of leaves and different nitrogen fertilization levels had higher CF\% than the tubers, and leaf under $40 \mathrm{~kg} \mathrm{~N} / \mathrm{ha}$ $\left(\mathrm{N}_{1} \mathrm{~L}\right)$ attained the highest crude fibre content during both seasons.

Ether extract\%: Data in Table (1) show highly significant differences between nitrogen fertilization levels on $E E \%$ in the first season only.

Leaves were superior in ether extract over tubers during both seasons. This result was relevant with those obtained by Nadaf et al. (1998b).

Significant nitrogen application $x$ fodder beet parts interaction was present in the second season when the highest EE\% was recorded for leaves under 80 $\mathrm{Kg} \mathrm{N} / \mathrm{ha}\left(\mathrm{N}_{2} \mathrm{~L}\right)$ while in the first season leaves under $40 \mathrm{Kg} \mathrm{N} / \mathrm{ha}\left(\mathrm{N}_{1} \mathrm{~L}\right)$ attained the highest ether extract with a highly significant difference.

Ash\%: Nitrogen application had no significant effect on ash\% during both seasons. However, leaf ash\% exceeded that of tuber highly significantly in both seasons. This agrees with the work of Nadaf et al. (1998a) on three fodder beet cultivars. They reported that ash content of leaves ranged between 25 and $28 \%$ on dry matter basis which is closer to the ash content of our results (23 and $24.25 \%$ on DM basis). The highest ash percent recorded for leaves under control $\left(\mathrm{N}_{0}\right)$ or $120 \mathrm{~kg} \mathrm{~N} / \mathrm{ha}\left(\mathrm{N}_{3}\right)$ during both seasons, may be resulting from effect of nitrogen on nutrient absorption

Nitrogen free extract\%: Nitrogen free extract was higher under higher nitrogen levels. Similar trend was observed by Abdallah and Yassen (2008) who reported an increase in total carbohydrates with increasing fertilizer rate.

The tubers were highly significantly richer in nitrogen free extract compared to leaves in both seasons. Similar observations were found by Mazuela and Pilar (1991); Sidak and Miroshnickenko (1993) and Brudziak et al. (1994).

Nitrogen $X$ beet parts interaction resulted in higher contents of nitrogen free extract obtained by tubers under control (0) in the first season and $120 \mathrm{~kg} \mathrm{~N} / \mathrm{ha}$ $\left(\mathrm{N}_{3}\right)$ in the second season. It seems that beet parts had greater effect on nitrogen free extract than nitrogen application.

Minerals: Table (2) illustrates the effects of nitrogen fertilization, beet parts and their interaction on minerals contents.

Nitrogen\%: Increasing nitrogen fertilizer levels up to $80 \mathrm{~kg} \mathrm{~N} / \mathrm{ha}\left(\mathrm{N}_{2}\right)$ increased nitrogen content highly significantly in the first season and only significant in the second one. Similar result was obtained by Lopez-Bellido et al. (1994) who found a maximum nitrogen uptake with increasing nitrogen fertilizer rates.Leaves highly significantly exceeded tubers in nitrogen content. Nadaf et al. (1998a) stated that content of nitrogen was slightly higher in leaves than in tubers. Leaves under $40 \mathrm{~kg}$

$\mathrm{N} / \mathrm{ha}\left(\mathrm{N}_{1} \mathrm{~L}\right)$ and $120 \mathrm{~kg} \mathrm{~N} / \mathrm{ha}\left(\mathrm{N}_{3} \mathrm{~L}\right)$ attained the greatest nitrogen content highly significantly in the first and second seasons, respectively. 
Table 1: Chemical composition of fodder beet affected by nitrogen fertilization, beet parts and their interactions for 2007-08 and 2008-09

\begin{tabular}{|c|c|c|c|c|c|c|c|c|c|c|c|c|c|}
\hline \multirow{2}{*}{\multicolumn{2}{|c|}{ Treatments }} & \multicolumn{2}{|c|}{ DM (\%) } & \multicolumn{2}{|c|}{ CP (\%) } & \multicolumn{2}{|c|}{ CF (\%) } & \multicolumn{2}{|c|}{ EE (\%) } & \multicolumn{2}{|c|}{ Ash (\%) } & \multicolumn{2}{|c|}{ NFE (\%) } \\
\hline & & $2007 / 08$ & $2008 / 09$ & $2007 / 08$ & $2008 / 09$ & $2007 / 08$ & $2008 / 09$ & $2007 / 08$ & $2008 / 09$ & $2007 / 08$ & $2008 / 09$ & $2007 / 08$ & $2008 / 09$ \\
\hline \multirow{4}{*}{ Nitrogen } & NO & $12.01 \mathrm{a}$ & $11.09 \mathrm{~b}$ & $7.27 \mathrm{c}$ & $9,95 \mathrm{~b}$ & $8.00 b$ & $9.03 \mathrm{a}$ & $1.16 \mathrm{c}$ & $2.33 \mathrm{a}$ & $20.00 \mathrm{a}$ & $18.13 \mathrm{a}$ & $63.58 a$ & $60.33 \mathrm{~b}$ \\
\hline & N1 & $11.19 \mathrm{~b}$ & $11.51 \mathrm{a}$ & $9.98 \mathrm{~b}$ & $9.98 \mathrm{~b}$ & $9.25 a b$ & $8.93 \mathrm{a}$ & $1.45 \mathrm{~b}$ & $2.45 \mathrm{a}$ & $17.63 \mathrm{a}$ & $15.85 \mathrm{a}$ & $61.70 \mathrm{a}$ & $59.65 \mathrm{~b}$ \\
\hline & N2 & $10.59 \mathrm{~d}$ & $10.43 \mathrm{c}$ & $10.33 a$ & $10.22 \mathrm{a}$ & $8.50 a b$ & $8.28 \mathrm{a}$ & $1.44 \mathrm{~b}$ & $2.60 \mathrm{a}$ & $17.75 \mathrm{a}$ & $16.63 \mathrm{a}$ & $61.99 \mathrm{a}$ & $62.29 \mathrm{a}$ \\
\hline & N3 & $10.98 \mathrm{c}$ & $10.41 \mathrm{c}$ & $7.23 \mathrm{c}$ & $10.00 \mathrm{ab}$ & $9.88 \mathrm{a}$ & $8.25 \mathrm{a}$ & $1.81 \mathrm{a}$ & $2.38 \mathrm{a}$ & $19.00 \mathrm{a}$ & $19.00 \mathrm{a}$ & $62.09 \mathrm{a}$ & $60.38 \mathrm{ab}$ \\
\hline \multirow{2}{*}{$\begin{array}{l}\text { F-test } \\
\pm S E\end{array}$} & & $\star \star$ & $\star \star$ & ** & $\star$ & * & NS & $\star *$ & NS & NS & NS & NS & * \\
\hline & & 0.005 & 0.044 & 0.015 & 0.030 & 0.329 & 0.294 & 0.005 & 0.79 & 0.563 & 1.475 & 0.672 & 0.479 \\
\hline \multirow{2}{*}{$\begin{array}{l}\text { Beet } \\
\text { Parts }\end{array}$} & Leaf (L) & 9.05 & 9,38 & 11.07 & 12.91 & 12.00 & 10.99 & 1.81 & 2.54 & 23.00 & 24.25 & 52.10 & 49.31 \\
\hline & tuber $(\mathrm{T})$ & 13.34 & 12.34 & 6.31 & 7.16 & 5.81 & 6.25 & 1.12 & 2.34 & 14.19 & 10.55 & 72.58 & 72.00 \\
\hline \multirow{3}{*}{$\begin{array}{c}\text { F-test } \\
\pm S E \\
\text { LSD }\end{array}$} & & $\star \star$ & $\star \star *$ & $\star \star$ & $\star *$ & $\star \star$ & $\star \star$ & $\star \star$ & $*$ & $\star \star *$ & $\star *$ & $\star \star$ & $\star \star$ \\
\hline & & 0.007 & 0.044 & 0.012 & 0.029 & 0.159 & 0.106 & 0.004 & 0.048 & 0.099 & 1.122 & 0.187 & 0.187 \\
\hline & & 0.03 & 0.17 & 0.04 & 0.12 & 0.62 & 0.42 & 0.01 & 0.20 & 0.39 & 4.41 & 0.73 & 0.74 \\
\hline \multirow{8}{*}{$\begin{array}{l}\text { Nitrogen } \\
X \text { parts }\end{array}$} & NO L & $9.74 \mathrm{e}$ & $9.63 \mathrm{~d}$ & $11.03 \mathrm{c}$ & $12.61 \mathrm{c}$ & $11.25 \mathrm{a}$ & $10.80 \mathrm{a}$ & $1.69 \mathrm{c}$ & $2.55 \mathrm{ab}$ & $24.50 \mathrm{a}$ & $25.50 \mathrm{a}$ & $51.53 \mathrm{c}$ & 48.55 ef \\
\hline & $\mathrm{NOT}$ & $14.29 \mathrm{a}$ & $12.56 \mathrm{~b}$ & $3.50 \mathrm{~h}$ & $7.30 \mathrm{de}$ & $4.75 \mathrm{a}$ & $7.25 \mathrm{~b}$ & $0.63 \mathrm{f}$ & $2.10 \mathrm{c}$ & $15.50 \mathrm{~d}$ & $10.75 a$ & $75.62 \mathrm{a}$ & $72.11 b$ \\
\hline & N1 L & $9.13 \mathrm{f}$ & $9.26 \mathrm{e}$ & $13.30 \mathrm{a}$ & $12.87 \mathrm{~b}$ & $12.75 \mathrm{a}$ & $11.35 \mathrm{a}$ & $1.92 \mathrm{a}$ & $2.50 \mathrm{abc}$ & $20.50 \mathrm{c}$ & $24.50 \mathrm{a}$ & $51.53 \mathrm{c}$ & $48.78 \mathrm{e}$ \\
\hline & $\mathrm{N} 1 \mathrm{~T}$ & $13.24 b$ & $13.76 \mathrm{a}$ & $6.65 \mathrm{f}$ & $7.09 \mathrm{ef}$ & $5.75 \mathrm{a}$ & $6.50 \mathrm{bc}$ & $0.98 \mathrm{e}$ & $2.40 \mathrm{bc}$ & $14.75 \mathrm{~d}$ & $7.20 \mathrm{a}$ & $71.87 \mathrm{~b}$ & $70.51 \mathrm{c}$ \\
\hline & N2 L & $8.39 \mathrm{~h}$ & $9.36 \mathrm{~d} \mathrm{e}$ & $11.55 b$ & $13.04 a b$ & $11.50 \mathrm{a}$ & $10.80 \mathrm{a}$ & $1.80 \mathrm{~b}$ & $2.85 \mathrm{a}$ & $22.50 \mathrm{~b}$ & $20.50 \mathrm{a}$ & $52.66 \mathrm{c}$ & $52.81 \mathrm{~d}$ \\
\hline & $\mathrm{N} 2 \mathrm{~T}$ & $12.80 \mathrm{~d}$ & $11.50 \mathrm{c}$ & $9.10 \mathrm{~d}$ & $7.39 d$ & $5.50 \mathrm{a}$ & $5.75 \mathrm{~cd}$ & $1.08 \mathrm{~d}$ & $2.35 \mathrm{bc}$ & $13.00 \mathrm{e}$ & $12.75 \mathrm{a}$ & $71.32 \mathrm{~b}$ & $71.76 \mathrm{bc}$ \\
\hline & N3 L & $8.94 \mathrm{~g}$ & $9.27 \mathrm{e}$ & $8.50 \mathrm{e}$ & $13.13 a$ & $12.50 \mathrm{a}$ & $11.00 \mathrm{a}$ & $1.82 \mathrm{~b}$ & $2.25 b c$ & $24.50 \mathrm{a}$ & $26.50 \mathrm{a}$ & $52.68 \mathrm{c}$ & $47.12 \mathrm{f}$ \\
\hline & N3 T & $13.03 \mathrm{c}$ & $11.56 \mathrm{c}$ & $5.95 \mathrm{~g}$ & $6.87 f$ & $7.25 \mathrm{a}$ & $5.50 d$ & $1.80 \mathrm{~b}$ & $2.50 \mathrm{abc}$ & $13.50 \mathrm{e}$ & $11.50 \mathrm{a}$ & $71.50 \mathrm{~b}$ & $73.64 \mathrm{a}$ \\
\hline \multirow{2}{*}{$\begin{array}{l}\text { F-test } \\
\pm S E\end{array}$} & & $\star \star$ & ** & $\star \star$ & $\star \star *$ & NS & * & ** & $*$ & ** & NS & $\star \star$ & ** \\
\hline & & 0.013 & 0.088 & 0.025 & 0.58 & 0.319 & 0.211 & 0.007 & 0.097 & 0.198 & 2.245 & 0.374 & 0.375 \\
\hline
\end{tabular}

NS: Not significant $\quad$ *: Significant $(5 \%) \quad$ **: Highly Significant $(1 \%)$

Means within each column followed by the same letters are not significantly different at (5\%) level according to DMRT.

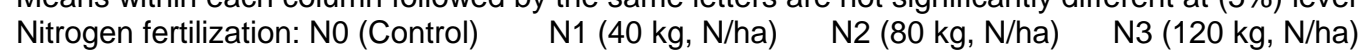


Table 2: Minerals composition of fodder beet affected by nitrogen fertilization, beet parts and their interactions for 2007-08 and 2008-09

\begin{tabular}{|c|c|c|c|c|c|c|c|c|c|c|c|}
\hline & \multicolumn{2}{|c|}{ N (\%) } & \multicolumn{2}{|c|}{ P (\%) } & \multicolumn{2}{|c|}{ K (\%) } & \multicolumn{2}{|c|}{$\mathrm{Na}(\%)$} & \multicolumn{2}{|c|}{$\mathrm{Cl}(\%)$} \\
\hline & & $2007 / 08$ & $2008 / 09$ & $2007 / 08$ & $2008 / 09$ & $2007 / 08$ & $2008 / 09$ & $2007 / 08$ & $2008 / 09$ & $2007 / 08$ & $2008 / 09$ \\
\hline \multirow[t]{4}{*}{ Nitrogen } & NO & $1.17 \mathrm{c}$ & $1.59 \mathrm{~b}$ & $0.23 \mathrm{a}$ & $0.12 b$ & $2.33 \mathrm{a}$ & $1.40 \mathrm{a}$ & $7.35 \mathrm{a}$ & $3.48 \mathrm{~b}$ & $1.16 \mathrm{a}$ & $0.68 \mathrm{~b}$ \\
\hline & N1 & $1.60 \mathrm{~b}$ & $1.60 \mathrm{~b}$ & $0.29 \mathrm{a}$ & $0.14 \mathrm{a}$ & $2.32 \mathrm{a}$ & $1.48 \mathrm{a}$ & $6.20 \mathrm{a}$ & $3.60 \mathrm{a}$ & $1.12 \mathrm{ab}$ & $0.73 \mathrm{a}$ \\
\hline & N2 & $1.66 \mathrm{a}$ & $1.64 \mathrm{a}$ & $0.23 \mathrm{a}$ & $0.12 \mathrm{~b}$ & $2.89 \mathrm{a}$ & $1.45 \mathrm{a}$ & $6.58 \mathrm{a}$ & $3.38 \mathrm{~b}$ & $1.10 \mathrm{~b}$ & $0.73 \mathrm{a}$ \\
\hline & N3 & $1.15 \mathrm{c}$ & $1.60 \mathrm{~b}$ & $0.30 \mathrm{a}$ & $0.15 \mathrm{a}$ & $2.92 \mathrm{a}$ & $1.45 \mathrm{a}$ & $6.80 \mathrm{a}$ & $3.38 \mathrm{~b}$ & $1.08 \mathrm{~b}$ & $0.73 \mathrm{a}$ \\
\hline \multicolumn{2}{|l|}{$\pm \mathrm{SE}$} & 0.009 & 0.006 & 0.038 & 0.004 & 0.354 & 0.032 & 0.363 & 0.024 & 0.010 & 0.004 \\
\hline \multicolumn{2}{|l|}{ F-test } & $\star \star$ & * & NS & * & NS & NS & NS & * & $\star$ & $\star \star$ \\
\hline Beet Parts & $\begin{array}{l}\text { Leaf }(\mathrm{L}) \\
\text { tuber }(T)\end{array}$ & $\begin{array}{l}1.77 \\
1.02\end{array}$ & $\begin{array}{c}2.02 \\
1.15\end{array}$ & $\begin{array}{l}0.26 \\
0.27\end{array}$ & $\begin{array}{l}0.15 \\
0.12\end{array}$ & $\begin{array}{l}2.81 \\
2.42\end{array}$ & $\begin{array}{l}1.34 \\
1.55\end{array}$ & $\begin{array}{l}6.66 \\
6.80\end{array}$ & $\begin{array}{l}3.16 \\
3.75\end{array}$ & $\begin{array}{l}1.37 \\
0.86\end{array}$ & $\begin{array}{l}0.69 \\
0.74\end{array}$ \\
\hline \multirow{8}{*}{$\begin{array}{l}\text { Nitrogen X parts ( } \mathrm{N} \\
\mathrm{P})\end{array}$} & $\begin{array}{l} \pm S E \\
\text { F-test } \\
\text { (LSD) }\end{array}$ & $\frac{0.01}{1.770}$ & $\frac{0.02}{202 h}$ & $\frac{-}{021 h^{2}}$ & $\frac{0.01}{0.120}$ & $\frac{-}{2210}$ & 0.14 & $\frac{-}{7600}$ & 0.14 & 0.01 & 0.02 \\
\hline & NO T & $\begin{array}{l}1.77 \mathrm{C} \\
0.57 \mathrm{~h}\end{array}$ & $\begin{array}{l}2.02 \mathrm{~b} \\
1.17 \mathrm{~cd}\end{array}$ & $\begin{array}{l}0.21 \mathrm{bc} \\
0.26 \mathrm{abc}\end{array}$ & $\begin{array}{l}0.13 \mathrm{a} \\
0.12 \mathrm{a}\end{array}$ & $\begin{array}{l}2.34 \mathrm{a} \\
2.32 \mathrm{a}\end{array}$ & $\begin{array}{c}1.25 \mathrm{c} \\
1.55 \mathrm{ab}\end{array}$ & $\begin{array}{l}7.60 \mathrm{a} \\
7.10 \mathrm{a}\end{array}$ & $\begin{array}{c}3.05 \mathrm{f} \\
3.90 \mathrm{ab}\end{array}$ & $\begin{array}{c}1.3 / \mathrm{ab} \\
0.95 \mathrm{c}\end{array}$ & $0.66 \mathrm{~d}$ \\
\hline & $\mathrm{N} 1 \mathrm{~L}$ & $2.12 \mathrm{a}$ & $2.06 a b$ & $0.28 \mathrm{abc}$ & $0.16 \mathrm{a}$ & $2.46 \mathrm{a}$ & $1.30 \mathrm{c}$ & $5.90 \mathrm{a}$ & 3.15 def & $1.37 \mathrm{ab}$ & $0.69 \mathrm{bcd}$ \\
\hline & $\mathrm{N} 1 \mathrm{~T}$ & $1.07 \mathrm{f}$ & $1.14 \mathrm{de}$ & $0.30 \mathrm{ab}$ & $0.12 \mathrm{a}$ & $2.18 \mathrm{a}$ & $1.65 \mathrm{a}$ & $6.50 \mathrm{a}$ & $4.05 \mathrm{a}$ & $0.87 d$ & $0.78 \mathrm{a}$ \\
\hline & $\mathrm{N} 2 \mathrm{~L}$ & $1.85 \mathrm{~b}$ & $2.09 a$ & $0.30 a b$ & $0.14 \mathrm{a}$ & $3.13 \mathrm{a}$ & $1.45 \mathrm{abc}$ & $6.45 \mathrm{a}$ & 3.10 ef & $1.39 \mathrm{a}$ & $0.71 \mathrm{~b}$ \\
\hline & $\mathrm{N} 2 \mathrm{~T}$ & $1.47 \mathrm{~d}$ & $1.19 \mathrm{c}$ & $0.16 \mathrm{c}$ & $0.11 \mathrm{a}$ & $2.65 \mathrm{a}$ & $1.45 \mathrm{abc}$ & $6.70 \mathrm{a}$ & $3.65 b c$ & $0.82 \mathrm{e}$ & $0.76 \mathrm{a}$ \\
\hline & N3 L & $1.35 \mathrm{e}$ & $2.10 \mathrm{a}$ & $0.25 \mathrm{abc}$ & $0.17 \mathrm{a}$ & $3.31 \mathrm{a}$ & $1.35 \mathrm{bc}$ & $6.70 \mathrm{a}$ & $3.35 \mathrm{de}$ & $1.36 \mathrm{~b}$ & $0.67 \mathrm{~cd}$ \\
\hline & N3 T & $0.96 \mathrm{~g}$ & $1.10 \mathrm{e}$ & $0.35 \mathrm{a}$ & $0.13 \mathrm{a}$ & $2.54 \mathrm{a}$ & $1.55 \mathrm{ab}$ & $6.90 \mathrm{a}$ & $3.40 \mathrm{~cd}$ & $0.81 \mathrm{e}$ & $0.78 \mathrm{a}$ \\
\hline \multicolumn{2}{|l|}{ \pm SE } & 0.003 & 0.010 & 0.034 & 0.005 & 0.482 & 0.053 & 0.477 & 0.08 & 0.006 & 0.009 \\
\hline \multicolumn{2}{|l|}{ F-test } & $\star \star *$ & $\star \star *$ & * & NS & NS & $*$ & NS & * & $\star \star *$ & $\star *$ \\
\hline
\end{tabular}

NS: Not significant

*: Significant $(5 \%)$

**: Highly Significant (1\%)

Means within each column followed by the same letters are not significantly different at (5\%) level according to DMRT. 
Agric. Biol. J. N. Am., 2011, 2(2): 270-278

Table 2: Contd.

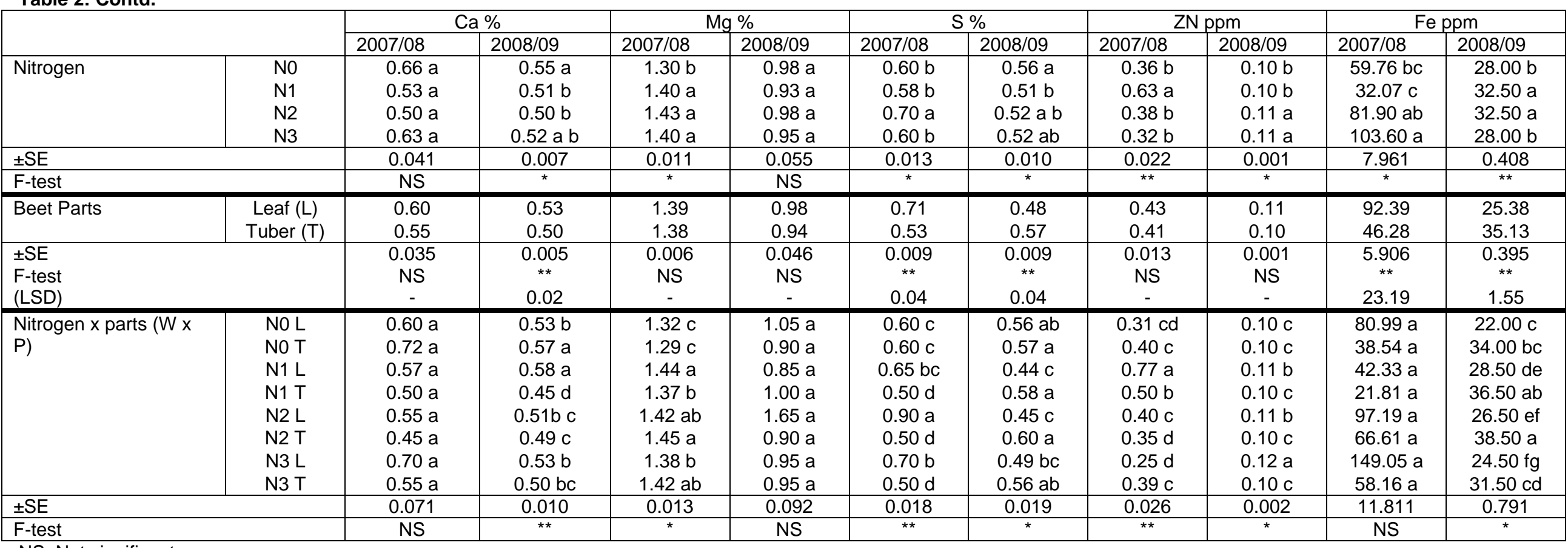

NS: Not significant

*: Significant (5\%)

**: Highly Significant (1\%)

Means within each column followed by the same letters are not significantly different at (5\%) level according to DMRT method. 
Phosphorus\%: Nitrogen caused inconsistent increase in phosphorus content of beet with a significant effect in the second season. Anac et al. (1999) reported a non-steady change in leaf phosphorus under different nitrogen levels.

Leaves had highly significantly higher phosphorus content than tubers in the second season. Magat and Goh (1990) reported a variation in chemical composition of tops and roots of beet plants.

The significant interactive effect of nitrogen and beet parts on phosphorus content in the first season revealed the effect of nitrogen on $P$ uptake and leaves as the main sink for $\mathrm{P}$ (Marschner, 1986).

Potassium\%: Potassium percentage was insignificantly increased by nitrogen application in both seasons as was reported by Mustafa (2007).

Tubers attained significantly higher potassium content than leaves in the second season. Magat and Goh (1990) reported that the chemical composition of fodder beet varies between tops and roots of the plant.

The two factors interaction between nitrogen fertilization and beet leaves and tubers on potassium content was significant in the second season when the highest percentage was recorded for tubers under $40 \mathrm{~kg} \mathrm{~N} / \mathrm{ha}\left(\mathrm{N}_{1} \mathrm{~T}\right)$. In that season tubers significantly exceeded leaves in potassium content and the effect of $N_{1}(40 \mathrm{~kg} \mathrm{~N} / \mathrm{ha})$ was slightly higher than other nitrogen levels, henceforth the combined significant effect of $N_{1} T$. Roots are the main sinks of $K$ because it translocates assimilates from leaves to storage roots.

Sodium\%: Nitrogen fertilization significantly increased sodium percent in the second season. Gutstein (1968) claimed that nitrogen fertilizer increased the absorption of sodium element.

The higher sodium percent recorded for tubers since they are the main sinks of $\mathrm{Na}$ and it transports assimilates from leaves to storage roots.

Sodium content was significantly affected by the interactive effect of nitrogen fertilization and beet parts in the second season when the highest content was achieved by tuber under $40 \mathrm{~kg} \mathrm{~N} / \mathrm{ha}$.Nitrogen has appositive effect on $\mathrm{Na}$ uptake and the roots are the main sink of $\mathrm{Na}$ (Marchener, 1988).

Chloride:Chloride showed inconsistent response to the different treatments during both seasons. In the first season, nitrogen application significantly reduced chloride content and vice versa for the second season with a highly significant difference.Also, in the first season leaves had significantly higher $(p<0.01)$ percentage of chloride than tubers and the reverse was true in the second one.

Nitrogen application $X$ beet parts highly significantly affected chloride percentage in both seasons. Leaves with $80 \mathrm{~kg} \mathrm{~N} / \mathrm{ha}$ attained the highest chloride content in the first season while tubers under $40 \mathrm{~kg} \mathrm{~N} / \mathrm{ha}$ $\left(\mathrm{N}_{1} \mathrm{~T}\right)$ and $120 \mathrm{~kg} \mathrm{~N} / \mathrm{ha}\left(\mathrm{N}_{3} \mathrm{~T}\right)$ recorded the greatest chloride percentage in the second season. This might have been due to inconsistent change of chloride affected by different doses of nitrogen (Anac et al., 1999).

Calcium\%: In the second season calcium percentage was reduced by nitrogen application as reported by Abd EL Gwad et al. (1989).

The higher content of calcium in leaves than tubers in contrast to that obtained by Nadaf et al. (1998a) may indicate the cultivar difference in chemical composition as was pointed out by Magat and Goh (1990).

Nitrogen application $X$ beet parts had highly significant effect on calcium content in the second season when leaves with $40 \mathrm{~kg} \mathrm{~N} / \mathrm{ha}\left(\mathrm{N}_{1} \mathrm{~L}\right)$ attained the greatest calcium percentage which may reflect that nitrogen induces formation of soft tissues or that high nitrogen depletes $\mathrm{Ca}$ in soil .

Magnesium\%: Magnesium content significantly increased by the same amount under different nitrogen levels (40, 80 and $120 \mathrm{~kg} \mathrm{~N} / \mathrm{ha})$ in the first season. Nitrogen application may have depleted $\mathrm{Mg}$ in the soil, so that no further increase in Mg occurred at high nitrogen levels.

In both seasons magnesium percentage of the leaves was slightly higher than tubers. Similar observation was made by Nadaf et al. (1998a).

The greatest percentages of magnesium were recorded for leaves with $40 \mathrm{Kg} \mathrm{N} / \mathrm{ha}(\mathrm{N} 1 \mathrm{~L})$ and tubers under $80 \mathrm{Kg} \mathrm{N} / \mathrm{ha}$ (N2T) in the first season. Nitrogen may deplete soil $\mathrm{Mg}$.

Sulfur\%: The reduction in sulfur content in the second season caused by nitrogen application was confirmed by Hago and Burhan (2000) who stated that increasing nitrogen fertilization decreases sulfur content of the plant. A contradicting trend was observed in the first season when $80 \mathrm{Kg} \mathrm{N}$ /ha significantly attained the highest sulfur content. Also, leaves exceeded tubers in sulfur content highly significantly in the first season while the reverse was 
true in the second season. Moreover, leaves and tubers with $80 \mathrm{Kg} \mathrm{N}$ /ha (N2L and N2T) obtained the greatest sulfur content in the first and second seasons, respectively. This may be due to variation between seasons.

Zink\%: The increase in zink content caused by nitrogen fertilization in both seasons was confirmed by Raymond and Spedding (1966).

In both seasons zink content of leaves insignificantly exceeded that of the tubers. The greatest contents of zink recorded for leaves under nitrogen fertilization was expected because of the positive effect of nitrogen application in increasing zink content and that leaves are the main sink for zink (Marschner,1988).

Iron\%:Increasing nitrogen levels to $120 \mathrm{~kg} \mathrm{~N} / \mathrm{ha}\left(\mathrm{N}_{3}\right)$ significantly increased iron content in the first season, while in the second season the increase was highly significantly till $80 \mathrm{~kg} \mathrm{~N} / \mathrm{ha}\left(\mathrm{N}_{2}\right)$. This may indicates the enhancing role of nitrogen in absorption of the mineral from the soil (Nollar and Rhykerd, 1974).

Leaves had higher iron content than tubers in the first season which was also reported by Nadaf et al. (1998a). In the second season leaves obtained lower amount than tubers.

\section{CONCLUSIONS}

*Nitrogen fertilization improved nutritive value of fodder beet (N2: $80 \mathrm{~kg} \mathrm{~N} / \mathrm{ha}$ significantly increased both crude protein $(10.27 \%)$ and nitrogen free extract (62\%) and increased the mineral contents.

* Leaves had higher contents of crude protein, crude fiber, ether extract and ash, nitrogen, phosphorus, calcium and magnesium than roots and the reverse was true for dry matter, nitrogen free extract, potassium and sodium.

ACKNOWLEDGMENT: We acknowledge with great gratitude the Scientific Research Council-Sudan University of Science and Technology for financing this research.

However, chloride, sulfur and iron of beet parts showed inconsistent variation. Nitrogen fertilization and beet parts interaction increased contents of nitrogen and chloride highly significantly $(p<0.01)$ in both seasons, calcium in the second season, zink and sulfur in the first season. Nitrogen $X$ beet parts interaction significantly $(p<0.05)$ increased phosphorus and magnesium in the first season and potassium and sodium, sulfur, zink and iron in the second season.

\section{REFERENCES}

A.O.A.C. (1984). Official methods of analysis, $14^{\text {th }}$ ed. Association of Analytical Chemistry, Washington, D.C.

Abd El Gwad, A.A., Nur El Din, N.A. and Faid, T.B. (1989). Introductory to Crops Sciences - Principles of Production.AL dar Alarabia of Publication and Press.355p.

Abdallah, E.F. and Yassen, A.A. (2008). Fodder beet productivity under fertilization treatments and water augmentation. Australian journal of Basic and Applied Sciences, 2 (2): 282-287.

Anac, D., Eryüce, N., Gürbüuz, O., Eryüce, B., Kilic, C. and Tutam, M. (1999). Improved Crop Quality by Nutrient Management. Springer Netherlands, 39-41.

Bruzdziak, M., Krolikowski, P. and Nowak, W. (1994). Influence of nitrogen fertilization level on yield of four Fodder beet varieties. Zeszyty-Naukowe-AcademiRolniczej/we-wroklawiu-Rolnoctwo (Poland), 238: 121132.

Chapman, H.D. and Pratt, P.F. (1961). Methods of analysis of soil, plants and waters. Division of Agricultural Science, University of California, 309 p.

Chatterjee, B.N. and Das, P.K. (1989). Forage Crop Production: Principles and Practices. Oxford and IBH Pub. Co. Pvt. Ltd., New Delhi, 450 p. [C.F. Nadaf, S.K., Ibrhaim, Y.M., Akhtar, M., El Hag, M.G. and Al-Lawati, A.H. (1998a). Performance of Fodder beet in Oman. Annals of Arid Zone, 37 (4): 377-382.

Cooper,J.P.(1972).Forage Production for cutting and Conservation .Proc. $6^{\text {th }}$ Conger.Eucarpia 53-64.

Gomez, K.A. and Gomez, A.A. (1984). Statistical procedures for agricultural research. $2^{\text {nd }}$ edition, john Willy and sons Inc. New York. 680p.

Gutstein, Y. (1968). The uptake of nitrogen, potassium and sodium, their interrelated effects on yield and quality composition of Sugar beet. Plant Foods for human Nutrition, 15 (1): 1-28.

Hago, T.E.M. and Burhan, H.O. (2000). Principles of crops production. (In Arabic). $1^{\text {st }}$ edition, Khartoum University Press. 276 p.

HTTP://www.ars-grin.gov/cgi-bin/npgs/html/taxon (1987).

HTTP://www.biologie.uni-hamburg.de/bonline/schaugaren/varalba/fodder-beet (2006).

Ibrahim, Y.M. (2005). Ranges and forage (In Arabic). Dar Azza for Publication, Khartoum, Sudan, 300p. 
Kipps, M.S. (1970). Production of field crops (A textbook of Agronomy). Sixth edition. McGraw-Hill, Inc. New York.790p.

Lopez-Bellido, L., Castillo, J.E. and Fuentes, M. (1994). Nitrogen uptake by autumn sown Sugar beet. Nutrient Cycling in Agroecosystems, 38 (2): 101-109.

Magat, S.S. and Goh, K.M. (1990). Effects of chloride fertilizers on ionic composition cation anion balance and ratio of Fodder beet (Beta vulgaris L.) grown under field conditions. New Zealand Journal of Agricultural Research, 33 (1): 29-40.

Marschner, H. (1988). Mineral Nutrition of Higher Plants. $2^{\text {nd }}$ edition. Academic Press Limited, London.

Martin, J.H., Leonard, W.H. and Stamp, D.L. (1976). Principles of field crop production. Third edition. MacMillan Publishing Co., Inc., New York.1118p.

Mazueala, A. and Pilar, C. (1991). Evaluation of five Fodder beet varieties (Beta vulgaris L. var crapa) in Valdivia (chile). 94p.

Mstat, V.4. (1986): A microcomputer program for the design management and analysis of agronomic research experiments. Michigan State University, USA.

Mustafa, M. El. (2007). Effect of nitrogen and phosphorus fertilization on the performance of three Sugar beet (Beta vulgaris L.) cultivars. M.Sc. Thesis, Faculty of Agriculture, University of Khartoum, Sudan.

Nadaf, S.K., Al-Khamisi, S., El Hag, M.G., Al-Lawati, A.H. and Ibrahim, Y.M. (1998b). Regional workshop on management of soils and crops. Arab Organization for Agricultural Development (AOAD), Muscat, Oman.

Nadaf, S.K., Ibrhaim, Y.M., Akhtar, M., El Hag, M.G. and Al-Lawati, A.H. (1998a). Performance of Fodder beet in Oman. Annals of Arid Zone, 37 (4): 377-382.
Noller, C.H. and Rhykeral, C.L. (1974). Relationship of nitrogen fertilization and chemical composition of forage to animal health and performance. In: Forage Fertilization, edt by Mays, D.A. pp. 363-394. [C.F.ElTakriti, El-A.R, El-Hassan, A.M. and El-Tamimi. M.A.(1987).Quality of Forage Crops(In Arabic. Dar- Alkutob of publication and press. 300p].

Paska, L. (1994). Selected aspects of management of Fodder beet production systems in the Slovac republic. Polnohospodarstvo (slovakia). 41: 178-190.

Patel, A.S., Sadhu, A.C., Patel, M.R. and Patel, P.C. (2007). Effect of zinc, FYM and fertility levels on yield and quality of forage maize (Zea Mays L.). Forage Research, 32: 209-212.

Raymond, W.F. and Spedding, C.R.W. (1966). Nitrogenous fertilizers and the feed value of grass. In: Nitrogen and Grassland. EDT. By VanBurg and Arnold, p. 151-160. [C.F. El-Takriti, El-A.R, El-Hassan, A.M. and ElTamimi. M.A. (1987).Quality of Forage Crops (In Arabic. Dar- Al-kutob of publication and press. 300p].

Sidak, V.A. and Miroshnichenko, V.A. (1993). Crop yield and sowing quality of seeds in different seed plants of Fodder beet. Selektsiya-I-Semenovostvo (Russian Federation), 1: 47-51. [C.F. Nadaf, S.K., Al-Khamisi, S., El Hag, M.G., Al-Lawati, A.H. and Ibrahim, Y.M. (1998b). Regional workshop on management of soils and crops. Arab Organization for Agricultural Development (AOAD), Muscat, Oman].

Vansoest, P.J. (1982). Nutritional Ecology of the Ruminant. Corvallis, Oreg: O and B books, lowa State University Press, USA. [C.F.Dougherty. C. T. and Rhykerd, C. L. (1985). The Role of Nitrogen in Forage Animal Production In: Forage The Science of Grassland Agricultural. $4^{\text {th }}$ edition. Lowa state University Press, U.S.A pp 318-325]. 